\title{
An Evaluation of South Africa's Application of the OAU Refugee Definition
}

\author{
Tal Hanna Schreier
}

\begin{abstract}
This paper undertakes an analysis of South Africa's application of the OAU Convention's expanded refugee definition. It finds that in the first stage of South Africa's refugee status determination process, government officials tasked with individually determining refugee status seemingly make use of the OAU Convention's refugee definition and basic country of origin information in a unique form of prima facie refugee determination. In this regard, improved training of officials is essential in order to ensure that the appropriate level of protection to all asylum seekers is afforded in terms of the definition. At the South African Refugee Appeal Board level, however, due to the in-depth nature of the decisions rendered, the OAU refugee definition is more correctly, yet cautiously, utilized to provide protection to persons fleeing indiscriminate widespread disruption of public order or generalized violence. This research is the first of its kind to analyze select decisions of the South African Refugee Appeal Board.
\end{abstract}

\section{Résumé}

Cet article entreprend une analyse sur la façon dont la définition élargie de réfugié proposée par la Convention de l'OUA est appliquée par l'Afrique du Sud. Il conclut qu'au premier stade de la procédure Sud africaine de détermination du statut de réfugié, les responsables gouvernementaux chargés de la détermination du statut de réfugié au niveau individuel semblent utiliser la définition de réfugié contenue dans la Convention de l'OUA ainsi que l'information de base sur le pays d'origine pour faire une détermination prima facie, unique en son genre, du statut de réfugié. À cet égard, il est impératif que les responsables gouvernementaux reçoivent une meilleure formation afin d'assurer un niveau de protection approprié à tous les réfugiés en ce qu'il s'agit de la définition. Cependant, au niveau du South African
Refugee Appeal Board (la Commission d'appel des réfugiés de l'Afrique du Sud), vu la nature approfondie des décisions rendues, la définition de réfugié de l'OUA est plus correctement - mais aussi prudemment - utilisée pour fournir une protection aux personnes qui fuient des perturbations étendues et indiscriminées de l'ordre public, ou la violence généralisée. Cette étude est la première en son genre à analyser des décisions sélectionnées du South African Refugee Appeal Board (la Commission d'appel des réfugiés de l'Afrique du Sud).

\section{Introduction}

The 1969 OAU Convention Governing Specific Aspects of Refugee Problems in Africa ${ }^{1}$ (OAU Convention) is, to date, the only legally binding regional refugee treaty and is regarded as a "cornerstone of refugee protection in Africa. ${ }^{2}$ Nearly forty years on, the OAU Convention remains an essential means of providing protection to large numbers of persons who are forced to flee their countries of origin due to indiscriminate widespread disruption of public order or generalized violence, with its most celebrated feature being the expansion of the refugee definition ${ }^{3}$ to provide protection to such persons.

South Africa's refugee protection system is still in its nascent stage of development, having only commenced after the demise of Apartheid regime in the mid 1990s. In 1995 and 1996 respectively, South Africa signed the OAU Convention and the Convention relating to the Status of Refugees (Refugee Convention). ${ }^{4}$ Shortly thereafter, South Africa enacted its Refugees Act 130 of 1998, which became operational in the year 2000. The Refugees Act incorporates both the 1951 Convention and OAU Convention refugee definitions, thus providing for expanded refugee protection in the Republic. ${ }^{5}$

The OAU refugee definition and the OAU Convention as a whole have not been subject to much interrogation; neither 
have they been the subject of much international jurisprudence. Similarly, South Africa's analysis of the OAU refugee definition has been less than noteworthy. To date, there exist no published Refugee Appeal Board decisions, or reported or unreported South African High Court decisions that have interpreted the OAU refugee definition. In general, refugee law jurisprudence in South Africa is thin, save for a number of cases related mainly to asylum procedure. Moreover, reliable statistics from the South African Department of Home Affairs or other sources, which may detail the extent of the application of the OAU refugee definition in practice, are not readily available, if not non-existent.

In analyzing some of the key elements of the OAU refugee definition as well as the approach to refugee determination in the country, this paper will attempt to ascertain whether, in the South African context, the expanded refugee definition is providing the necessary protection to certain individuals, as envisaged by the OAU Convention. A detailed analysis of selected Refugee Appeal Board decisions on topic will assist in determining the current level of protection afforded by the South African refugee regime in this regard.

\section{South Africa's Refugee Determination Process and the OAU Definition: A Form of Prima Facie Refugee Status Determination?}

At the outset, it is necessary to determine to whom the OAU refugee definition specifically applies. This question arises because of the definition's words "every person," which need to be considered. According to Micah Rankin, some African States view the OAU refugee definition as applying only to Africans. The basis for this position may possibly be found in the Convention's main objective, that as a regional complement to the Refugee Convention, it was created in order to meet the specific needs of African refugees, which may suggest an intention on the part of its drafters to limit its territorial application to Africa. ${ }^{6}$ However, the plain meaning of the words "every person" clearly points to a more inclusive interpretation, meaning that the definition's application ought to be universal. Furthermore, the Refugee Convention's universal application, stemming from the same inclusive wording, provides evidence of the requirement of similar application. This broader line of interpretation is also more consistent with the expanded definition's aim to extend asylum rather than to refuse it. ${ }^{7}$ Notwithstanding this point, the actual position that the South African government takes in relation to the scope of the OAU refugee definition is what remains relevant to the within study. In this regard, it is necessary to examine what transpires in South Africa's refugee determination procedure.

In South Africa, it is the responsibility of the Department of Home Affairs (the Department) to determine the status of refugees. This is done by way of a status interview conducted by a Department official, known as a Refugee Status Determination Officer (RSDO). A rejected asylum seeker has the right to review of the RSDO's decision by the Refugee Appeal Board or by the Standing Committee for Refugee Affairs, two quasi-judicial tribunals created in terms of the Refugees Act.

While the Refugees Act provides for special measures or powers of the Minister of Home Affairs to be taken in times of a mass influx of refugees into the country, ${ }^{8}$ it was anticipated and in fact legislated that, in the normal course, at first instance each asylum seeker in South Africa receives an individual refugee status determination. However, research indicates that in South Africa the individual process of refugee status determination improperly makes use of the OAU refugee definition in a unique form of prima facie refugee determination, ${ }^{9}$ which is a process normally used in times of mass influx or emergency. This is because

it appears that South Africa applies a form of prima facie asylum determination that is not related to a mass-influx situation, but rather depends on whether it is "obvious" than an applicant is a refugee, based on the danger and instability within a part of the applicant's country of origin. ${ }^{10}$

Ingrid van Beek explains this point further by asserting that in South Africa "there is not only a mixed understanding of the definition of 'prima facie refugees' ... but on what is perceived as a mass influx situation." ${ }^{11}$ Van Beek's research included interviews with Department officials, who stated that South Africa was experiencing a situation of mass influx as determined by reference to the actual number of asylum seekers that were entering the country. Interestingly, several years later, in a recent report by the Refugee Affairs Directorate, Department of Home Affairs, this very same conclusion is echoed. Refugee Affairs, throughout its 2006 Annual Report on Asylum Statistics, concludes that South Africa is still experiencing a mass influx of asylum seekers into the country. ${ }^{12}$

In this regard, there is a clear inconsistency that exists in terms of the legislative intent of the Refugees Act as compared to the actual understanding and practice of Department officials at the refugee reception offices. More specifically, the Department is on one hand stating that there is a mass influx of asylum seekers into the country, thereby legitimizing its use of the OAU refugee definition in order to fast-track refugee status determinations. However, on the other hand, the Minister has never implemented the special provisions, in terms of her powers under section 35 of the Refugees Act, to deal with a mass influx of asylum seekers into the country, if such was really the case. The special provisions that the Minister may invoke 
include the accommodation of any specific category or group of asylum seekers or refugees in camps or refugee reception centres. To add to the confusion, nowhere in the Refugees Act is the term "mass influx" actually defined.

Therefore, while there is no official mass influx into South Africa at this time, it seems that the Department's approach to refugee status determination in fact relies on the application of the OAU refugee definition to assist in accelerating or fast-tracking applications based on a prima facie recognition of refugee status. This can likely be explained as a result of the endemic resource and capacity shortages at the Department of Home Affairs, Refugee Affairs Directorate, ${ }^{13}$ which "pose serious challenges for Refugee Affairs ... and have overwhelmed the already fragile refugee services." 14

Anais Tuepker comments that, in the process of fasttracking applications within South Africa's refugee status determination procedure, which includes the use of unofficial or non-legislated practices such as pre-screening processes, ${ }^{15}$ reliance on implicit "white lists" of refugee producing countries, and the focus on merely confirming the nationality of an asylum seeker, indicates that the "institutional culture [among the Department] overwhelmingly supports an automatic link between nationality and refugeehood which produces the shared knowledge that asylum is only really for a select group of nationals." 16

In terms of RSDOs' focusing on the nationality of an asylum seeker, Lee Anne de la Hunt describes the following practice in more detail as follows:

While the Department of Home Affairs denies keeping a list of "refugee producing countries" or a "white list" there is clearly a mindset or institutional culture within the department that determines who is a refugee and who is not, based on the asylum seeker's country of origin. The focus of this country-oriented approach is that, particularly in relation to countries whose nationals are very likely to be granted asylum (Somalia, for example), the focus of the determination hearing is on getting the asylum seeker to "prove" his or her nationality on the basis of his or her knowledge of demographics, culture and language, geography and the political landscape. ${ }^{17}$

The aforementioned practices relied upon by Department officials are evidenced by the fact that the majority of recognized refugees in South Africa "are from countries in Africa where civil, generalized conflict and the breakdown of public order are endemic." 18 De la Hunt surmises that the Department's acceptance rates fluctuate depending on the government's assessment of the situation in the countries from which the asylum seekers hail. ${ }^{19}$ She further reasons that the high acceptance rates from these countries are made on the basis of the OAU refugee definition, in that:

\begin{abstract}
... the letters advising refugees that their asylum claims have been successful merely state this fact .... [while] most of the rejection letters start by declaring that the asylum seeker has failed to prove that he or she has a well-founded fear of persecution, but then go on to give a (usually standardized) assessment of the situation within the country of origin (for example, that the country of origin is a democracy that protects its citizens) with very little analysis, of the actual claim itself, or its merits. ${ }^{20}$
\end{abstract}

The year-on-year increase in the number of asylum seekers arriving in South Africa undoubtedly places a burden on the already strained refugee services in the country. To some extent therefore it is understandable that "at least implicitly ... Home Affairs officials prefer easy acceptances on the basis of the OAU definition; it also appears, however, that they do not deal satisfactorily with claims arising from the Convention's narrower definition based on a persecution standard."21

As a consequence of the Department's approach that the OAU definition patently supports the notion of refugeegenerating countries, there appears to be another disturbing practice amongst the Department's officials, related to the limiting of the number of applicants who can apply for asylum. Many asylum seekers are simply refused entrance to the refugee reception offices. For the most part, this practice is recognizably arbitrary and based on the large numbers of asylum seekers that queue outside the offices each day, ${ }^{22}$ but it may also be on account of an applicant's nationality. In this regard, the following specific examples come to mind. Two particular clients at the author's office, one of Nepalese nationality and the other from Fiji, were time and again denied access to the Cape Town Refugee Reception Office, having been advised by Home Affairs officials that Nepal and Fiji are "safe countries" and that they therefore could not be asylum seekers.

According to the above, therefore, it would seem as if at first instance, i.e. at the RSDO interview level, the OAU refugee definition or section 3(b) of the Refugees Act is in fact only applied to African asylum seekers. Tuepker confirmed this fact in an interview she conducted with an official of the Department of Home Affairs: Head Office. ${ }^{23}$ Furthermore, L. de la Hunt concludes that "both the [Department of Home Affairs asylum] statistics themselves, as well as conversations with Home Affairs officials, indicate that the benefits of the extended definition are only available to African refugees." 24

Aside from the fact that the legislative framework for refugee status determination in South Africa does not provide for the type of prima facie refugee status determination which has clearly emerged, another particular problem that may arise with the use of such a practice is that such refugee status determinations fail to recognize that some applicants from "refugee-generating" countries may also have individ- 
ualized refugee claims or, in other words, a well-founded fear of persecution. Ignoring this fact, or not providing each asylum seeker with the opportunity to fully explain, in a formal application process, his or her individualized reasons for fleeing his or her country, may have a negative effect on that refugee later on if or when the Department decides to invoke cessation of the refugee's status, based on the fact that the presumed conditions which caused the refugee to flee cease to exist. ${ }^{25}$

\section{The Position of the Refugee Appeal Board}

According to the author's experience and as per the literature reviewed, the first-instance RSDO decisions in South Africa's asylum process are generally of such poor quality that a specific determination as to their application of the OAU definition cannot be properly gleaned. In this regard, the RSDOs' decisions granting an applicant refugee status do not provide reasons for same, for example, whether the applicant was approved in terms of a particular section of the Refugees Act. Rather, such decisions simply state “ ... [T] he application for asylum in respect of yourself has been approved ... and your formal recognition of refugee status is hereby attached." 26 Furthermore, while decisions rejecting an asylum seeker's application must set out reasons for same, they usually only set out the applicant's claim in a short paragraph, and then proceed to reject the claim based on reasons to the effect that the applicant could not establish a well-founded fear of persecution. The lack of sufficient and/or continuous training of RSDOs, as well as lack of adequate resources to conduct country-of-origin research, likely accounts for the poor quality of these decisions.

It is therefore necessary to examine the decisions of the Refugee Appeal Board, which are generally more detailed, including a thorough review of the appellant's refugee claim, up-to-date country-of-origin information and international jurisprudence, used to accept or reject an appellant's claim. The Refugee Appeal Board has itself on numerous occasions acknowledged the poor quality of the RSDO's decisions; i.e., rather than conducting an appeal in the true sense, ${ }^{27}$ the Refugee Appeal Board deems its hearings to be de novo hearings in which the Board in effect conducts a fresh refugee status determination hearing with the appellant. ${ }^{28}$

Unfortunately, to date, the Refugee Appeal Board has officially made public only two of its decisions, ${ }^{29}$ which makes it very difficult to properly ascertain or determine its jurisprudence. Fortunately, despite the dearth of appeal decisions made available at this time, through her many interactions with the Refugee Appeal Board in the course of her employment, the author has been able to pose questions of the Appeal Board members in an attempt to better understand its interpretation of the OAU definition. In terms of the scope of application of the Refugees Act section 3(b), in other words whether the OAU definition applies to every person or only to every African, the Chairperson of the Refugee Appeal Board responded to the author's question as follows:

... [T] he Board would apply [Section 3(b) of the Refugees Act] to anyone from any part of the world and not only Africans. The reasons here fore is that when the OAU Convention was incorporated into the Refugees Act, it did not specify that it would only apply to the African continent but was left open so to speak. ${ }^{30}$

In terms of the whether the Internal Flight Alternative (IFA) may be applied to a person who takes flight as a result of a section 3(b) event, the Chairperson of the Appeal Board, on behalf of the Board, advised ${ }^{31}$ that the Board is not wholly in agreement with the position taken by UNHCR or James Hathaway, its interpretation being that the IFA does not apply, as the definition clearly states that the event need only take place in either part of the whole of an applicant's country of origin or nationality. In this regard, the Board is of the opinion that, if possible, an asylum seeker needs to have exhausted all internal remedies in his or her country of origin, prior to seeking protection abroad. This is in line with the notion of "surrogate protection," in which the international community is only required by law to provide asylum when a person's government is unable to do so itself. In this regard, for example, it would not be possible or reasonable for a forced migrant from an event seriously disturbing the public order in Goma, in the eastern part of the Democratic Republic of the Congo (DRC), to be required to travel to the very faraway capital city of Kinshasa, whereas fleeing across the border into a neighbouring country is safer and more practical. However, if internal flight from a location in which an OAU event took place to one in which there is safety within the country is possible and not unduly difficult for the individual, then the Board feels that the IFA issue may be raised.

Lastly, with regard to the issue of a whether or not a person may become a sur place refugee according to the OAU refugee definition, the Chairperson of the Refugee Appeal Board stated the following:

... the OAU Convention or section 3(b) of the Refugees Act, 1998, cannot apply to a sur place case because of the wording of the definition or section i.e. you must be compelled to leave your habitual place of residence ... If you were not compelled to leave then it cannot apply. However, looking at the wording of section 2 of the Refugees Act, 1998, read with section 3 of the Act, it is clear that a person [fearing a section 3(b) or OAU event] must be granted asylum sur place. ${ }^{32}$ 


\section{Some Refugee Appeal Board Decisions Reviewed}

According to section 26(1) of the Refugees Act, "any asylum seeker may lodge an appeal with the Appeal Board ... if the Refugee Status Determination Officer has rejected the application in terms of section 2(3)(c),"33 in other words, if the RSDO has rejected the application as unfounded. This automatic right to an appeal effectively means another layer added to the South African refugee determination procedure, since it is more often than not the case that rejected asylum seekers heavily rely on the appeal process for a proper decision on their claim and/or merely to prolong their stay in the country. The immense number of appeal cases already heard by the Appeal Board for which decisions are still pending and those which are scheduled to take place in the future, which currently runs well into 2009, is symptomatic of this situation.

For this research, the author was only able to obtain a small number of appeal decisions from the Refugee Appeal Board. In this regard, the Chairperson of the Appeal Board provided the author with approximately one hundred random appeal decisions, of which only eight decisions dealt with the section 3(b) refugee definition. Despite the small sample, the mere fact that only such a small percentage of appeal board decisions raise the section 3 (b) definition may indicate that most of the claims that fall within the ambit of section 3(b) are in fact properly adjudicated by RSDOs at first instance. Irrespectively, an evaluation of the decisions obtained provides a picture of the Appeal Board applying the OAU definition sensibly, yet at the same time rather cautiously.

Of the Appeal Board decisions obtained, five of them dealt with the general application of the section 3(b) definition. In this regard, rather than analyzing a particular element of the definition itself, these decisions reviewed the appellant's claim, then reviewed the conditions in the appellant's country of origin, and finally concluded, based on the situation in the appellant's country of origin, whether or not the asylum seeker qualified for refugee status in terms of this definition. In terms of these decisions, especially those in which the Appeal Board upheld the appeal and granted refugee status based on the application of section 3(b), the question remains as to why the RSDO at first instance did not apply the same country of origin research and reasoning to reach the conclusion that the asylum seeker must receive refugee protection. Unfortunately, due to the fact that the Refugee Appeal Board deems its hearings to be de novo ones, it is not possible when reviewing the Board's decision to assess the reasoning of the RSDO in coming to his or her negative decision at first instance for the same applicant. The author, however, on a number of occasions, has been advised by Department officials of the lack of sufficient internet facilities, hence country of origin research capabilities, of its RSDOs. This explanation may account for the incorrect application of the OAU definition at first instance as officials are unable to properly assess the situation in the applicant's country of origin.

In Refugee Appeal Board decision number 159/2004, ${ }^{34}$ the Appeal Board granted refugee status to a Somali national hailing from the country's war-ravaged capital city of Mogadishu, the appellant's place of habitual residence. The appellant's claim consisted of his fleeing Mogadishu due to generalized life-threatening factional clan fighting which was occurring throughout the city. In its decision, the Appeal Board referred to various 2003 country reports, which confirm the large number of civilian deaths in the city due to the continued fighting in the capital city. Interestingly, in this case, counsel for the appellant argued that her client should be granted refugee status based on an individualized or 1951 refugee claim and also argued that the appellant did not have an Internal Flight Alternative as he could not flee to "the northern part of the Somalia because he is from a different clan and will not be accepted there." 35 In this regard, the Appeal Board pointed out that counsel erred, as:

\footnotetext{
... its reasons for not returning the appellant to his country of origin falls within the ambit of section 3(b) of the Refugees Act, 1998, and not as prayed for by Counsel in terms of section 3(a) of the Act. Section 3(a) makes it clear that a person must have a well-founded fear of being persecuted for a specific reason mentioned in the section. This is not the case with section 3(b) where a person is compelled to leave his or her place of habitual residence because of, for instance, events seriously disturbing or disrupting public order and where persecution as such is not necessarily present. In this case, the appellant was compelled to leave Somalia because of the faction and clan fighting, in other words events seriously disturbing and/or disrupting public order, in order to seek refuge elsewhere. ${ }^{36}$
}

In another Appeal Board decision of a Somali national, the Appeal Board granted refugee status to the appellant who hailed from the southern Somali city of Kismayo. Similar to the above decision, according to this appellant's personal background it emerged that "nothing has ever happened to him personally and that his complaint is based on the ongoing clan-related fighting taking place in Kismayo and elsewhere in Somalia." ${ }^{37}$ After reviewing the appellant's claim, the Appeal Board went on to review a prominent country report on the situation in Somalia, which confirmed that the entire southern part of the country remains unstable due to chronic lawlessness and insecurity, hence “... [i]t is clear that anyone coming from the southern Somalia, such as Kismayo, whether anything has happened to them or not, fall within the group of asylum seekers needing international protection." 38 
According to the sample of decisions reviewed, it is evident that the Refugee Appeal Board also dismisses appeals on the basis of an analysis of the current conditions of the appellant's country of origin. In this regard, the Appeal Board uses documentary evidence or country reports to indicate that a change in country-of-origin conditions has taken place such that it is now, based on a forward-looking definition of a refugee, considered safe for the asylum seeker to return to his country of origin.

It is trite law that the refugee definition is a forwardlooking one, meaning that when a decision maker assesses whether someone qualifies for refugee status, he or she must determine if the asylum seeker will face persecution upon return to their country of origin. The Michigan Guidelines on Well-Founded Fear ${ }^{39}$ expand on this point, but specifically with regard to the element of fear in the 1951 refugee definition:

An understanding of "fear" as forward-looking expectation of risk is fully justified by one of the plain meanings of the [Refugee Convention's] English text, and is confirmed by dominant interpretations of the equally authoritative French language text ("craignant avec raison"), which do not canvass subjective trepidation. This construction avoids the enormous practical risks inherent in attempting objectively to assess the feelings and emotions of an applicant. It is moreover consistent with the internal structure of the Convention, for example with the principle that refugee status ceases when the actual risk of being persecuted comes to an end, though not on the basis of an absence of trepidation (Art. 1(C)5-6), and with the fact that the core duty of non-refoulement applies where there is a genuine risk of being persecuted, with no account taken of whether a refugee stands in trepidation of that risk (Art. 33). ${ }^{40}$

A similar approach, that of a forward looking assessment of risk, to refugee determination based on the OAU or section 3(b) refugee definition, also must take place when the RSDO or the Refugee Appeal Board is deciding upon an asylum seeker's claim. This position is also logically consistent with the cessation clause found in the Refugees Act, 1998 at section 5(1)(e), which provides that a person ceases to qualify for refugee status if "he or she can no longer continue to refuse to avail himself or herself of the protection of the country of his or her nationality because the circumstances in connection with which he or she has been recognized as a refugee have ceased to exist." ${ }^{41}$ In light of this fact, the Appeal Board appropriately assesses the prospective risk of an appellant by evaluating the current conditions in his or her country of origin.

With the above in mind, an example of the Board's forwardlooking assessment in terms of sections 3(b) and 5(1)(e) of the Refugees Act is found in Appeal Board decision number 4013/03, in which the Board dismissed the appellant's claim. In this case, which the Appeal Board heard in February 2004, the Rwandan national fled his country of origin when the genocide reached his village in 1994. The appellant arrived in South Africa in 1995 and, by letter dated 10 September 1997, the Standing Committee for Refugee Affairs declined to grant him refugee status. ${ }^{42}$ Once again, it is unclear why this decision was taken by the Standing Committee at the time, and in this regard, the Appeal Board confirms that "because the appeal hearing is a de novo procedure, the appellant does not have to prove that the Standing Committee was wrong ... [rather] the Board assesses the evidence given by the appellant and makes its own decision on the objective facts concerned." 43 In any event, in terms of its assessment of the appellant's claim, the Appeal Board had "no hesitation in finding that section 3(b) of the Refugees Act, 1998, applied to the appellant when he initially lodged his application for refugee status." ${ }^{44}$ However, the Appeal Board's decision to dismiss the claim was based on whether or not "the situation in Rwanda has changed to such an extent that it is safe for appellant to return there." ${ }^{45}$ In this regard, and based on the Appeal Board's review of 2004 and 2005 Rwanda situation reports, the Board determined that it would be safe for the appellant to return to his country.

The above decision brings an important issue to the fore, that being the implication of such an extensive delay in the decision-making process of the Department of Home Affairs and Refugee Appeal Board. In the case, the appellant arrived in South Africa in early 1995 and, ten years later his appeal to the Refugee Appeal Board was dismissed, based on a forward-looking assessment of risk. This means that while the appellant had a genuine refugee-related reason for fleeing his country ten years ago, at present, however, according to the Appeal Board, he could safely return there due to the changed circumstances in his country of origin. Unfortunately, this approach fails to take into consideration the impact of section 5(2) of the Refugees Act. This section states that cessation of refugee status based on section 5(1)(e) "does not apply to a refugee who is able to invoke compelling reasons arising out of previous persecution for refusing to avail himself or herself of the protection of the country of nationality." In the case of Mayongo v. Refugee Appeal Board \& Others ${ }^{46}$ the South African High Court, in a judicial review application of an Appeal Board decision dismissing an appeal of an Angolan asylum seeker, dealt with this issue specifically and granted the applicant refugee status. The Court held that

According to the UNCHR handbook a person is a refugee as soon as he/she fulfils the criteria contained in the definition. That takes place before he/she applies for refugee status.

(C) Tal Hanna Schreier, 2008. This open-access work is licensed under a Creative Commons Attribution-NonCommercial 4.0 International License, which permits use, reproduction and distribution in any medium for non-commercial purposes, provided the original author(s) are credited and the original publication in Refuge: Canada's Journal on Refugees is cited. 
Recogniblotion of refugee status does not make the person a refugee but only declares that he/se is one... . The RAB accepted that he was compelled to flee Angola. It follows that he was a refugee at the time. When the $\mathrm{RAB}$ dealt with the appeal it did not consider the impact of sections 5(1)(e) and 5(2) because the applicant never officially obtained refugee status. In that respect it made a basic error of law. It was in law compelled to determine whether the post-traumatic stress syndrome and major depressive disorder constituted a compelling reason to refuse to avail himself of the protection of the Angolan Government. ${ }^{47}$

In light of this Mayongo decision, the Appeal Board's decision in the Rwandan national's case described above may contain a similar basic error in law. The Board decided that the genocide in Rwanda fell within the meaning of a section 3(b) event, in other words, an event that compelled the appellant to flee his or her country because it seriously disrupted or disturbed the public order. In its decision, when reviewing the appellant's claim, the Appeal Board simply stated that the appellant was a Tutsi, who was forced to flee when the genocide reached his village. The author suggests that when the appellant arrived in South Africa, in terms of both the OAU and the Refugee Convention definitions, he would have qualified for refugee status. Not only did the Rwandan genocide qualify as an OAU event, but because the appellant was a Tutsi, he was specifically persecuted due to his race or tribe, as contemplated in the Refugee Convention definition. The ten-year delay in finalizing this asylum seeker's claim, led to the Appeal Board dismissing his claim based on a lack of a forward-looking assessment of risk, without taking into consideration possible circumstances of section 5(2) of the Refugee Act. Thus, the Appeal Board, having framed the reasons why the appellant fled his country to be a section 3(b) reason only, may have erred in its decision.

Two additional decisions of the Appeal Board examined by the author further highlight the significance of the forward-looking assessment of risk as discussed above. Both these Appeal decisions involved Burundian nationals. The first of these, decided on 6 May 2004, found that the appellant, who fled his country in 1998, was a refugee because "in the circumstances ... the change(s) in Burundi have not been shown to be durable." 48 This decision was reached after the Board reviewed country-of-origin information which showed that despite a ceasefire in Burundi, fighting was still taking place in the country, hence a durable change of circumstances could not be established. In this regard, the Appeal Board took into consideration Hathaway's following position on this point: "This condition (durability) is in keeping with the forward-looking nature of the refugee definition and avoids the disruption of protection in circumstances where safety may be only a momentary aberration." 49
Nearly three years later, however, in an Appeal Board decision dated 4 April 2007, the case of a Burundian appellant, who fled his country in 1997 when the civil war was rife in his country, was dismissed due to country-of-origin reports that indicated that "the conditions in Burundi are changing for the better." ${ }^{0}$ In this case, the Board found that "there have been no serious recurrences of the widespread armed conflict or serious human rights abuses that were widely reported in 2004 and that section 3(b) of the Refugees Act 130 of 1998 is no longer applicable," 51 hence it was safe for appellant to return to his country at this time.

The remaining Appeal Board decisions that the author reviewed relate to specific elements of the OAU or section 3(b) refugee definition. In this regard, the author examined two Appeal Board decisions in which the phrase "place of habitual residence" was considered. In Appeal Board decision number $378 / 05$, the appeal was upheld and refugee status granted to a female national of the DRC. The appellant was living and working in Uvira, and in September 2002 fled the generalized violence in that area, moving to Moba, another town in the DRC, where she remained for the next nine months. When the fighting reached Moba, she fled the country, eventually arriving in South Africa. She claimed she could not return to her country of origin, due to the ongoing fighting in the eastern part of the DRC. In this case, the Board stated that the principle issue to be decided was whether the appellant was compelled to leave her place of habitual residence in order to seek refuge elsewhere, in other words whether section 3(b) of the Refugees Act was applicable. In answering this question, the Board decided the following:

\footnotetext{
The last location where the appellant "resided" in the DRC was Moba where she had fled to after leaving Mulonge village in Uvira. The Board has reservations whether Moba can be seen as the appellant's [place of] habitual residence and finds that it was not whether or not she was compelled to leave it. The Board finds that Uvira was the appellant's place of habitual residence which she was compelled to leave in order to seek refuge elsewhere. The appellant's evidence indicates that she was compelled to leave her place of habitual residence due to events seriously disturbing or disrupting public order i.e. the fighting taking place in the eastern DRC and specifically Uvira. ${ }^{52}$
}

The Board's above interpretation relating to the appellant's place of habitual residence is, in essence, consistent with $\mathrm{M}$. Rankin's comments relating to incidents of delay between the time when a refugee is compelled to leave his or her place of habitual residence due to an OAU event and the time he or she arrives in the country of asylum. During this period, an individual may be internally displaced and thus have to take up residence in various secondary locations before finally 
fleeing the country. Whereas within the context of the 1951 Refugee Convention definition, a delay in taking flight may affect the asylum seeker's credibility, ${ }^{53}$ in terms of the OAU definition, a delay goes to the issue of whether someone has actually been compelled from their habitual residence. ${ }^{54}$ Rankin elaborates on this issue further as follows:

The short answer to the delay problem may be found in the concept of a continuing compulsion. That is the idea that having once fled from her place of habitual residence an asylum seeker will continue to be compelled so long as the displacement can be casually linked to an initial triggering event. ${ }^{55}$

In this same Appeal Board decision, the Board also confirms its cautious position taken with regard to the IFA, as described above. More specifically, in this regard the Board states:

The final question which the Board has to consider is whether in cases where section 3(b) of the Act is applicable, the internal relocation alternative can be applied or not. In this instance Counsel for the appellant has argued that it cannot be applied. The Board has certain reservations but for the purpose of this decision will go along with [Counsel's] argument. In the circumstances the appellant's appeal must succeed. ${ }^{56}$

In Refugee Appeal Board decision number 415/05, the Board again considered the issue of "place of habitual residence" when it dismissed the appellant's claim. In this case, the appellant, a national from the DRC, was living in Lubumbashi, but was on a fishing trip with friends during school holidays in Moba. When appellant and his friends received news that rebels were coming, they attempted to return home to Lubumbashi but they encountered government troops in the town of Pweto. The soldiers accused the appellant and his friends of being rebels and then forced the appellant to fight with them against the rebels. Shortly thereafter, the appellant was able to escape in an attack by the rebels on the army soldiers, and fled the country, eventually arriving in South Africa. The appellant stated that when he fled, he was afraid to return to Lubumbashi because he would be accused of being a rebel and that furthermore he could not return to the DRC because of the war situation in the eastern Congo. The Board found that the appellant "did not habitually reside at Moba or at Pweto in the lower eastern part of the DRC" 57 because he and his friends were there on vacation. The Board therefore concluded that "it is clear that section 3(b) of the Refugees Act, 1998, has no application here as the appellant, and his friends, were not compelled to leave their place of habitual residence to seek refuge elsewhere."58 The Board furthermore decided that the appellant's assertion that he would be considered a rebel was implausible, and that Lubumbashi is under government control and according to country information is safe from fighting. Accordingly, the appellant was denied refugee status. This decision demonstrates an appropriate analysis on the part of the Appeal Board regarding the application of the OAU refugee definition. It furthermore reveals a situation in which the Appeal Board properly assesses an appellant's claim from the viewpoint of both the Refugee Convention and the OAU refugee definitions.

Lastly, the final Appeal Board decision obtained by the author for the purposes of this paper focuses on the Board's specific interpretation of the meaning of a disruption or disturbance of the public order. In Refugee Appeal Board decision number 1433/06, the Appeal Board dismissed the appeal of a Nigerian asylum seeker based on its interpretation of this aspect of the 3(b) definition. In this case, the appellant claimed that, as a Christian, he was fearful of the fighting taking place in his country between Christians and Muslims, although "he was unable to state exactly where the fighting was taking place." 59 In its decision, the Board reviewed country of origin information on Nigeria, which confirmed that "there were incidents of violence between Muslims and Christians between 2001 and 2004 mainly in the Plateau and Kano states ... [and] in reaction to the religious violence, President Obassanjo declared a state of emergency." ${ }^{60}$ Furthermore, another report confirmed that as a result of violent incidents between Christians and Muslims during February 2006 in the city of Onitsha, from where the appellant hailed, the "state governor deployed 2000 policemen on the streets and appealed for calm." According to these reports, the Board concluded that "the government [of Nigeria] is taking an active role in preventing and/or stopping the violent incidents between Christians and Muslims"61 and that the "government is doing all it can to prevent or control violent incidents between the two religious groups." In turning to the application of section 3(b) of the Refugees Act, the Board concluded that the definition does not apply in this case, as events disrupting or disturbing the public order implies "that the government is no longer in control," 62 which according to the Board "is not the case in Nigeria at all, [since] the government is firmly in control." 63

This interpretation of the Appeal Board of "events seriously disturbing or disrupting public order" is seemingly a narrow one. A government's attempts, no matter how genuine, to suppress or subdue serious disruptions or disturbances of public order should not be the litmus test for the application of this definition, since generalized violence and massive human rights violations may nonetheless take place, thereby compelling someone to take flight. The effectiveness of a government's attempts must therefore be considered as well. 
While the above case involved a clearly weak refugee claim, in that the appellant could not even point to specific events that compelled him to take flight, the Board in this decision nevertheless demonstrated a restrictive analysis, as nowhere did it question the ability of the Nigerian government to control the unrest that had occurred. The following decision of the Appeal Board reviewed by the author is, however, more instructive on this point.

In the course of her employment, the author has come across only one other Appeal Board decision, which provides further insight into the Board's interpretation of section 3(b) of the Refugees Act, and which complements the above decision. In Refugee Appeal Board decision number 729/06, in which the Board dismissed the appeal of a Burundian asylum seeker, the Board stated the following:

Where law and order has broken and the government is unwilling or unable to protect its citizens, it can be said that there are events seriously disturbing or disrupting public order. To determine when a disturbance had taken place involves weighing the degree and intensity of the conduct complained of against the degree and nature of the peace which can be expected to prevail in a given place at a given time. The test should be objective. ${ }^{64}$

This quote provides some clarity as to the Board's interpretation of "events seriously disrupting public order," as here the Appeal Board refers to the necessary ability of a government to protect its citizens in the face of an OAU or section 3(b) event. Accordingly, it can be stated that the Board takes the position that only when an asylum seeker's government is "unwilling or unable to protect" its citizens in the face of law and order having broken down, does this constitute a section 3 (b) event. What is unclear or undefined, however, is the precise meaning of "law and order breaking down."

\section{Conclusions}

In light of the continuing trend that has seen the narrowing of the scope of application of the Refugee Convention definition, resulting in the denial of protection to people who require safety for their lives outside of their country of origin or nationality, the expanded OAU refugee definition represents an "opposite trend [and] is what comprises its true value for refugee jurisprudence at a global level." 65 Whether or not in the South African context this is the case has been the focus of this paper; the question being whether South Africa is applying the expanded refugee definition sensibly and as such providing protection to those persons who may otherwise not qualify for refugee status in terms of the Refugee Convention definition. The answer to this question is a particularly difficult one. At the outset, assessing whether the definition is properly applied is critically hampered by the fact that the precise legal meaning of the OAU refugee definition is non-existent, and that comparative jurisprudence from other jurisdictions on the continent is not readily available.

Turning to South Africa's asylum determination procedure, one can conclude that, at first instance, the Department's reliance on the OAU refugee definition in the form of a prima facie procedure based on "white lists" or "refugee generating countries" is an inadequate approach, in that it may include generalized and hence incorrect assumptions about what constitutes an OAU or section 3(b) event and a lack of appropriate consideration of the other elements of the definition. Additionally, as there is currently no official mass influx situation in the country, such group determination violates the Refugees Act, which clearly provides for an individualized refugee status determination for each applicant. In examining only the objective conditions of a country, the RSDOs may also potentially disregard the subjective elements of an individual applicant's claim. In this regard, as van Beek correctly asserts, "a [refugee] determination procedure, which is only based on country information, neglects the fact that refugees also come from countries perceived to be safe ... [and] violates the principle of non-discrimination, written down in the South African Constitution and the UN and OAU Conventions." 66

This research concludes that, in terms of its application of the OAU Convention's refugee definition, it would appear that Department of Home Affairs officials are not sufficiently trained to apply the definition properly and that the asylum process itself, given the significant pressures it faces, does not allow for this to take place. Specific training on the nonexclusive application of the section 3(b) refugee definition should be provided, as well as a concerted effort to promote the expansion of the concept of refugee protection to all persons who do not have individualized claims of persecution in their countries of origin.

With regard to South Africa's Refugee Appeal Board decisions, a more considered and measured approach to the application of the OAU or section 3(b) refugee definition has been observed. From the limited number of decisions reviewed, it appears as though the Appeal Board is faithfully applying its mind to the numerous interpretative issues raised by the OAU refugee definition, and the Board's application of the expanded refugee definition is reasoned, although fairly limited or narrow in its scope. However, it may not be until such time as an Appeal Board's decision involving its interpretation of the expanded refugee definition is challenged on judicial review to the South African High Court that more meaningful jurisprudence will develop in this regard. 


\section{Notes}

1. 1969 OAU Convention Governing the Specific Aspects of Refugee Problems in Africa, adopted on 10 September 1969 by the Assembly of Heads of State and Government, CAB/ LEG/24.3 (entered into force on 20 June 1974 [OAU Convention].

2. The Addis Ababa Document on Refugees and Forced Population Displacements in Africa, adopted by the OAU/UNHCR Symposium on Refugees and Forced Population Displacements in Africa, Addis Ababa (8-10 September 1994) at para. 3 .

3. The OAU Convention firstly, in Art I(1), repeats the Refugee Convention refugee definition (with the 1967 Protocol's addition, which removed the geographical and temporal limitations from same) and then includes this additional definition of a refugee at $\operatorname{Art~I(2):~}$

... the term refugee shall also apply to every person who, owing to external aggression, occupation, foreign domination or events seriously disturbing public order in either a part or the whole of his or her country of origin or nationality, is compelled to leave his or her place of habitual residence in order to seek refuge in another place outside his country of origin or nationality.

4. Convention relating to the Status of Refugees, 28 July 1951, 189 U.N.T.S. 150 (entered into force 22 April 1954) [Refugee Convention]; and Protocol Relating to the Status of Refugees, 606 U.N.T.S. 267 (entered into force 4 October 1967).

5. Section 3(a) and 3(b) of the South African Refugees Act 130 of 1998 [Refugees Act].

6. M. Rankin, "Extending the limits or narrowing the scope? Deconstructing the OAU refugee definition thirty years on" (UNHCR Working Paper No. 113, April 2005) at 12, online: $<$ http://www.unhcr.org/research/RESEARCH/425f71a42. pdf $>$ (date accessed: 2 January 2008).

7. L. de la Hunt, "Refugee Law in South Africa: Making the Road of the Refugee Longer" in A Reference Guide to Refugee Law and Issues in Southern Africa (Lusaka: Legal Resources Foundation, 2002) at 34. De la Hunt supports this inclusive interpretation, claiming that the OAU definition should "apply universally and equally to all applicants, regardless of their country of origin."

8. Section 35 of the Refugees Act, entitled "Reception and accommodation of asylum seekers in event of mass influx," provides the Minister with the ability to grant refugee status to a group or category of persons, although what is meant by a group of persons is unclear.

9. The concept of "prima facie refugee determination" refers to the provisional granting of refugee status to a person or persons without the formal requirement of conducting an individual refugee status determination to establish whether or not the displaced person(s) qualify. Rather than the granting of refugee status based on a legal definition, prima facie refuge determination is essentially a device or a method to enable, in urgent situations such as a mass influx, appropriate protection measures to be taken when individual refugee status determination procedures are impractical. According to the UNHCR, in effect it is the number of refugees that triggers the mechanism for prima facie refugee status. See UNHCR Handbook on Procedures and Criteria for Determining Refugee Status under the 1951 Convention and the 1967 Protocol Relating to the Status of Refugees (1992), 13, at para. 44.

10. I. van Beek, "Prima facie asylum determination in South Africa: A description of policy and practice" in Perspectives on Refugee Protection in South Africa, ed. J. Handmaker, L. de la Hunt, and J. Klaaren (Pretoria: Lawyers for Human Rights, 2001), 18.

11. Ibid.

12. Department of Home Affairs, Directorate of Refugee Affairs, 2006 Annual Report on Asylum Statistics (January 2007), obtained by author from the UNHCR branch office in Pretoria; on file with author). This report states (at 4) that "during 2006, Refugee Affairs experiences multifaceted challenges in dealing with mass influx of asylum seekers" and states (at 6) that "the mass influxes of asylum seekers have overwhelmed the already fragile refugee services."

13. J. du Plessis, "Home Affairs puts in overtime" Pretoria News (28 April 2008).

14. Supra note 12 at 4.

15. Supra note 12 at 6 confirms that this practice still takes place, in order to "lessen administrative load of refugee offices, then redirect manifestly unfounded cases to relevant directorates and finally provide assistance to deserving asylum seekers."

16. A. Tuepker, "On the Threshold of Africa: OAU and UN Definitions in South African Asylum Practice" (2002) 15:4 Journal of Refugee Studies 418.

17. Supra note 7 at 36 .

18. Ibid, at 35 .

19. Ibid.

20. Ibid. at 36. This practice is confirmed by the author's personal experience, having through the course of her employment, read hundreds of RSDO's rejection letters, which predominantly state that the asylum seeker does not qualify for refugee status because while he or she showed fear of past persecution, it could not be found that he or she would be persecuted upon return to the country of origin.

21. Ibid. at 36 .

22. Supra note 13, in which the Department of Home Affairs estimates that "between 1000 to 2000 foreigners were trying to apply for [asylum seeker] permits every day."

23. Supra note 16 at 413.

24. Supra note 7 at 36.

25. Section 36 of the Refugees Act allows the Minister to withdraw refugee status from someone who ceases to remain a refugee for the reasons set out in Section 5 of the Refugees Act.

26. Pro forma letter appended to each B1-1155 Form (Refugee Regulations, 2000), also referred to as the Section 24 Refugee Status document. 
27. For example, by focusing on the first instance decision and allowing the appellant to argue grounds of appeal regarding same.

28. According to first-hand observations by the author between 2006 and 2008, the Appeal Board practice indicates this position. In this regard, the Board members usually advise the appellant that the appeal hearing is a de novo one. Furthermore, the Board members rarely refer to the appellant's file in order to confirm or dispute any facts stated at the Appeal, and reference by the appellant or his or her legal representative to an error made by the RSDO at first instance is usually only acknowledged by the Board member but not dealt with in detail.

29. Currently on the Department of Home Affairs website, online: $<$ http://www.dha.gov.za/raab.asp $>$ (accessed on January 28,2008 ). Incidentally, there exists no statutory obligation on the Board to report its decisions, in terms of the Refugees Act, its Regulations, or the Appeal Board Rules 2003.

30. Email response to author's question by Refugee Appeal Board Chairperson, Mr. Tjerk Damstra, July 32007 (notes on file with the author).

31. In a conversation with the author on 7 February 2008 (notes on file with the author).

32. Email response to author's question by Refugee Appeal Board Chairperson, Mr. Tjerk Damstra, 4 January 2008 (notes on file with the author).

33. Section 26(1) of the Refugees Act.

34. Upon providing the author with these decisions, the Chairperson of the Appeal Board requested the author to protect the anonymity of the appellants, hence the use only of the Appeal Board decision number to identify the decision reviewed.

35. Refugee Appeal Board decision number 159/2004 at 3 .

36. Ibid. at 7 .

37. Refugee Appeal Board decision number $418 / 05$ at 6 .

38. Ibid. at 7.

39. The Michigan Guidelines on Well-Founded Fear, Third Colloquium on Challenges in International Refugee Law Convened by the Program in Refugee and Asylum Law, University of Michigan Law School, March 26-28, 2004, online: $<$ http://www.refugeecaselaw.org/fear.pdf> (accessed 25 January 2008).

40. Ibid. at 4-5.

41. Section 5(1)(e) of the Refugees Act.

42. Prior to the Refugees Act being implemented, the Standing Committee for Refugee Affairs was the body that was responsible for individual refugee status determinations in South Africa.

43. Refugee Appeal Board decision number 4013/03, 6, at para. 20.
44. Ibid. at para. 18 .

45. Ibid. at para. 20.

46. Mayongo v. Refugee Appeal Board \& Others, 2007 J.O.L. 19645 (T).

47. Ibid. at para. 8-9.

48. Refugee Appeal Board decision number 294/04 at 5.

49. Ibid., quoting J. Hathaway, The Law of Refugee Status (Canada: Butterworths, 1991) at 203.

50. Refugee Appeal Board decision number 002/06 at para. 23 .

51. Ibid. at para. 24.

52. Refugee Appeal Board decision number 378/05 at para. 21-22.

53. Due to a delay in the asylum seeker fleeing his country, it may be determined that the harm that the asylum seeker was facing was not serious; in other words it did not amount to persecution, such that it required him or her to immediately flee the country. See supra note 12 at 25 , note 166 , on this point.

54. Supra note 6 at $24-25$.

55. Ibid. at 25 .

56. Refugee Appeal Board decision number 38/05 at para. 23 .

57. Refugee Appeal Board decision number 415/04 at para. 22.

58. Ibid

59. Refugee Appeal Board decision number 1433/06 at para. 8.

60. Ibid. at para. 18 .

61. Ibid. at para. 19.

62. Ibid. at para. 22

63. Ibid.

64. Refugee Appeal Board decision number 729/06 at para. 13.

65. G. Okoth Obbo, "Thirty Years On: A Legal Review of the 1969 OAU Refugee Convention Governing the Specific Aspects of Refugee Problems in Africa" (2001) 20:1 Refugee Survey Quarterly 79 at 113.

66. Supra note 10 at 28.

Tal Hanna Schreier, B.A., LL.B., LL.M., is a Canadian lawyer currently based in South Africa. She researched this paper while completing her LLM and working as Senior Refugee Legal Counsellor and Advocacy \& Training Coordinator at the University of Cape Town Law Clinic's Refugee Rights Project. The Project provides free legal support and services to refugees and asylum seekers in the Western Cape, as well conducting strategic litigation and advocating for the rights of refugees at all levels of government and society.

(C) Tal Hanna Schreier, 2008. This open-access work is licensed under a Creative Commons Attribution-NonCommercial 4.0 International License, which permits use, reproduction and distribution in any medium for non-commercial purposes, provided the original author(s) are credited and the original publication in Refuge: Canada's Journal on Refugees is cited. 